\title{
THERMAL EXPANSION OF NICKEL, MONEL METAL, STELLITE, STAINLESS STEEL, AND ALUMINUM
}

\author{
By Wilmer H. Souder and Peter Hidnert
}

ABSTRACT

Data on the thermal expansion of 29 samples of commercial nickel, monel metal, stellite, stainless steel, and exceptionally pure aluminum are presented. The apparatus used was essentially the same as that described in Scientific Paper of the Bureau of Standards, No. $35^{2}$.

CoMmERCiAl, NiCKEL.-A slight irregularity was perceptible near $35^{\circ} \mathrm{C}$, but there was no marked change or anomalous expansion such as was observed by previous investigators in the case of pure nickel.

MONEL, METAx.-The expansion curves of monel metal were found to be fairly regular. The average coefficients of expansion of the various samples (containing from 60 to 69 per cent nickel) are all practically equal for the range from 25 to $300^{\circ} \mathrm{C}$.

STELLITE. - The expansion curves show irregularities in the region between 300 and $500^{\circ} \mathrm{C}$. A hammered stellite was found to have smaller coefficients of expansion than an unhammered sample of corresponding composition.

STAINLESS STEEL. - The coefficients of expansion of the annealed and the hardened sample of stainless steel are less than the coefficients of ordinary iron or steel, which is probably due to the large amount of chromium. On heating, both samples indicated critical regions which extended from approximately 825 to approximately $855^{\circ} \mathrm{C}$. The transformation point on cooling occurred at about $800^{\circ} \mathrm{C}$.

ALUMINUM. - The thermal expansion of the two samples of aluminum investigated between room temperature and $600^{\circ} \mathrm{C}$ may be represented by the following empirical equation:

$$
L_{\mathrm{t}}=L_{\mathrm{o}}\left[\mathrm{I}+\left(2 \mathrm{1} .90 t+0.0120 t^{2}\right) 10^{-6}\right] \text {. }
$$

The average coefficients of expansion of the various materials for severai temperature ranges are given in Table 16.

\section{CONTENTS}

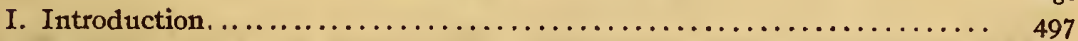

II. Apparatus. ....................................... 498

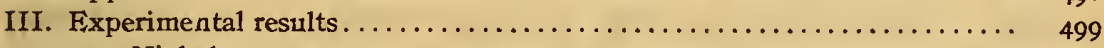

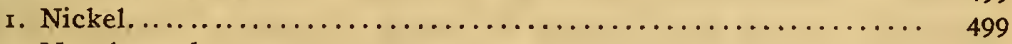

2. Monel metal................................. 504

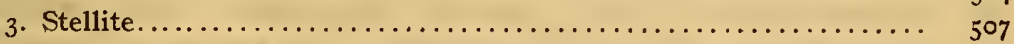

4. Stainless steel...............................

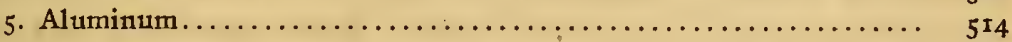

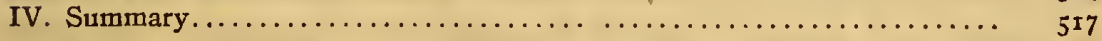

\section{INTRODUCTION}

The increasing use of nickel and nickel alloy wire in spark plugs, of monel metal for high-pressure steam valves, stems, seats, etc., of stellite for surgical and household uses, of stainless steel 
for numerous purposes, such as aeroplane and automobile engine valves, pump rods, and marine fittings, and of aluminum or its alloys, almost universally, where lightness is necessary; has created a demand for data on the thermal expansion of these materials. It is necessary to properly select the materials which are component parts of accurate apparatus in order to compensate for the varying expansions of these materials. Differential expansions between nickel and porcelain in spark plugs and between monel metal and steel or brass in steam valves are important factors to be considered by manufacturers of such articles.

This paper includes original data on the thermal expansion of Io samples of commercial nickel, ro samples of monel metal, 5 samples of stellite, 2 samples of stainless steel, and 2 samples of exceptionally pure aluminum, in addition to the results obtained by previous observers on the expansion of nickel and aluminum.

The samples of nickel and monel metal were prepared by the International Nickel Co., Bayonne, N. J.; the stellite specimens by the Haynes Stellite Co., Kokomo, Ind., through A. W. Gray, an employee of the L. D. Caulk Co., Milford, Del.; the samples of stainless steel by the Firth-Sterling Steel Co., McKeesport, $\mathrm{Pa}$; and the samples of aluminum by the Aluminum Company of America, New Kensington, $\mathrm{Pa}$. These companies also furnished the chemical compositions and previous treatments of the samples. Acknowledgment is due these companies for their cooperation and to R. L. Coleman, jr., and J. E. Wall, of the Bureau of Standards, for assistance in the tests, computations, and other work.

\section{APPARATUS}

The apparatus was essentially the same as that used in a similar investigation of the thermal expansion of insulating materials, to the description of which reference ${ }^{1}$ should be made for a description of the general procedure. The electrically heated air furnace illustrated in Fig. I of the same paper was used for practically all of the tests. Each specimen was $30 \mathrm{~cm}$ in length and about $\mathrm{I} \mathrm{cm}$ in diameter (or diagonal). In most instances the two observation wires (chromel, or alloy of platinum, and osmium), indicating the positions of the ends of the sample, were suspended from two $V$ notches cut around and at right angles to its axis, so that the wires were prevented from

1 B. S. Sci. Papers, No. 352; 1919. 
moving laterally in the direction of the length of specimen due to the formation of oxide films or scales, if any, at high temperatures. The only desirable lateral movements of the wires were those due to the changes in temperature of the specimen.

\section{EXPERIMENTAL RESULTS}

The results obtained on the thermal expansion of nickel, monel metal, stellite, stainless steel, and aluminum, in addition to the determinations by previous investigators on nickel and aluminum are given in the following subsections.

\section{NICKEL}

In 1869 Fizeau $^{2}$ published the value 0.00001279 for the coefficient of expansion of nickel at $40^{\circ} \mathrm{C}$. The sample had been previously reduced by hydrogen and compressed.

About 30 years later Tutton ${ }^{3}$ made nine individual determinations on the thermal expansion of pure nickel. He found that the rate of expansion (or instantaneous coefficient) at any temperature $t$ between 6 and $12 \mathrm{I}^{\circ}$ may be represented by the value

$$
0.00001248+0.0000000148 t \text {, or } 10^{-8}(1248+\mathrm{I} .48 t) \text {. }
$$

Holborn and Day ${ }^{4}$ made some measurements on the expansion of a nickel bar. From their observations, which were taken on five different days, average coefficients of expansion were computed which are given in the following table:

TABLE 1.-Coefficients of Expansion of Nickel (Holborn and Day)

\begin{tabular}{|c|c|c|c|c|c|}
\hline \multirow{2}{*}{ Temperature range in degrees centigrnde } & \multicolumn{5}{|c|}{ Average coefficients of expansion $\times 10^{6}$ on- } \\
\hline & June 30 & July 2 & July 4 & Sept. 18 & Sept. 19 \\
\hline 0 to $250 . \ldots \ldots \ldots \ldots$ & 13.8 & 13.9 & 14.2 & & \\
\hline 250 to $375 \ldots \ldots \ldots \ldots \ldots . . . . .$. & & 16.2 & & & \\
\hline 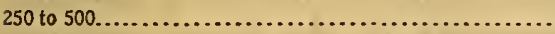 & 16. 2 & $\ldots \ldots \ldots$ & 16. 2 & & \\
\hline 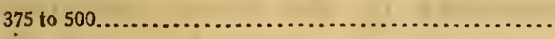 & ...... & 16.4 & ...... & -...... & $\ldots .$. \\
\hline 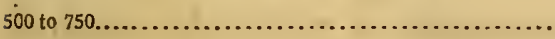 & 17.9 & 18.0 & 17.9 & & \\
\hline 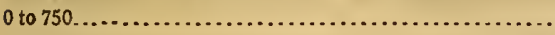 & n........ & ....... & n. & 15.9 & 15.9 \\
\hline 750 to $1000 \ldots . . . . . . . . . . . . . . . . . . . . . . .$. & & & & 19. 2 & 19.2 2 \\
\hline
\end{tabular}

Before the first test the rod of nickel was $482.6 \mathrm{~mm}$ at $0^{\circ}$. After each test the sample was approximately $0.02 \mathrm{~mm}$ shorter than before the test.

${ }^{2}$ Fizeau, Comptes Rendus, 68, p. II25, and Poggendorff's Annalen, 138, p. 30.

Tutton, Proc. Roy. Soc., Nos. 4 I5 and 419 ; 1899.

4 Holborn and Day, Annalen der Physik, 39 (IV ser.), p. I04; I9or. 
The observations can be represented by the following quadratic equation

$$
\lambda *=\left(13460 t+3.315 t^{2}\right) \text { 10 }^{9}
$$

only above $375^{\circ}$. Holborn and Day state that nickel undergoes a transformation in the region of $300^{\circ}$.

Harrison $^{5}$ determined the coefficients of expansion of a very pure specimen of nickel wire and commented as follows:

" $\mathrm{Up}$ to a temperature of about $365^{\circ}$ the curve is regular. Between 365 and $380^{\circ}$ there occurs an anomalous change in the expansion, while above $380^{\circ}$ the curve is again regular, though now it is linear, with a different slope to the regular part of the curve which precedes it. No difference in the position or shape of the anomalous portion of this curve was noticed, whether the temperature was rising or falling. It is also worthy of notice that in every case the wire returned after heating to its original length. There was no permanent elongation."

The following table gives average coefficients of expansion for ranges between $o$ and $550^{\circ}$ :

TABLE 2.-Average Coefficients of Expansion of Nickel Wire (Harrison)

\begin{tabular}{|c|c|c|c|}
\hline $\begin{array}{c}\text { Temperature range in degrees } \\
\text { centigrade }\end{array}$ & $\begin{array}{c}\text { Average } \\
\text { coefficients } \\
\text { of expansion }\end{array}$ & $\begin{array}{l}\text { Temperature range in degrees } \\
\text { centigrade }\end{array}$ & $\begin{array}{c}\text { Averago } \\
\text { coefflcients } \\
\text { of expansion }\end{array}$ \\
\hline 0 to $50 \ldots \ldots . . . \ldots \ldots . . .$. & 0.0000128 & 350 to $365 \ldots \ldots \ldots \ldots$ & 0.0000205 \\
\hline 50 to $100 \ldots \ldots \ldots \ldots \ldots \ldots$ & .0000136 & 380 to $400 \ldots \ldots \ldots \ldots . . . . . .$. & .0000191 \\
\hline 150 to $200 \ldots \ldots . . . . . . . . . . . . . .$. & .0000151 & 400 to $450 \ldots \ldots \ldots \ldots$ & .0000189 \\
\hline 250 to $300 \ldots \ldots \ldots \ldots . . . . . . . . .$. & .0000174 & 450 to $500 \ldots \ldots \ldots \ldots \ldots$ & .0000192 \\
\hline 300 to $350 \ldots \ldots \ldots$ & .0000191 & 500 to $550 \ldots \ldots \ldots$ & .0000190 \\
\hline
\end{tabular}

"The anomalous part of the curve extends from 340 to $370^{\circ}$, which is very approximately the range over which changes occur in the thermoelectric force and resistance of the same specimen of nickel. Moreover, it has recentiy been shown by the author, in some experiments not yet published, that this interval is also that over which the magnetic permeability of the same specimen changes-the actual critical temperature at which the susceptibility vanishes being just over $370^{\circ}$."

Harrison states that the cause of the anomalous change in expansion is to be sought for in the metal itself, although in the case of impure metals the true effect might be masked and modified by changes of a chemical nature.

\footnotetext{
$* \lambda$ represents the expansion or change per unit length from $0^{\circ}$ to any temperature $t$ (between 375 and $1000^{\circ} \mathrm{C}$.).

5 Harrison, Phil. Mag., 7 (sixth series), p. 626; 1904.
} 
Randall ${ }^{6}$ made two series of determinations of the coefficients of expansion of a cylinder of pure nickel furnished by Zeiss, Jena. His results are presented in two tables and a figure, which indicates a critical region between 280 and $370^{\circ}$. The coefficients of expansion of the second series are less than those of the first series. Randall's values are not given here, for he states that neither set of results can justly be considered as representing the coefficient of expansion of nickel, due to the fact that he did not thoroughly anneal the sample by repeated heatings before making observations.

Henning ${ }^{7}$ determined the linear expansion of nickel by comparing its change of length at various temperatures with the known expansion of platinum as determined by Scheel. The following table gives the linear expansion (or change in length) in millimeters of a $\mathrm{i}$ meter rod of nickel:

TABLE 3.-Expansion of Nickel (Henning)

\begin{tabular}{|c|c|c|c|}
\hline $\begin{array}{l}\text { Temperature range in degrees } \\
\text { centigrade }\end{array}$ & $\begin{array}{l}\text { Expansion } \\
\text { of } 1 \text { meter } \\
\text { rod }\end{array}$ & $\begin{array}{l}\text { Temperature range in degrees } \\
\text { centigrade }\end{array}$ & $\begin{array}{l}\text { Expansion } \\
\text { of } 1 \text { meter } \\
\text { rod }\end{array}$ \\
\hline+16 to $-191 \ldots \ldots \ldots \ldots \ldots \ldots \ldots \ldots$ & $\begin{array}{l}\mathrm{mm} \\
-2.095\end{array}$ & +16 to $500 \ldots$. & $\underset{7.336}{\mathrm{~mm}}$ \\
\hline+16 to $+250 \ldots \ldots \ldots \ldots \ldots \ldots$ & +3.268 & +16 to $750 \ldots \ldots \ldots . . . . .$. & 11.737 \\
\hline+16 to $375 \ldots \ldots \ldots \ldots$. & 5. 291 & +16 to $1000 \ldots . . . \ldots \ldots \ldots . . . .$. & 16.553 \\
\hline
\end{tabular}

From these results the average coefficients of expansion given in the following table were computed:

TABLE 4.-Coefficients of Expansion of Nickel (Henning)

\begin{tabular}{|c|c|c|c|}
\hline $\begin{array}{c}\text { Temperature range in degrees } \\
\text { centigrade }\end{array}$ & $\begin{array}{c}\text { Average } \\
\text { coefficients } \\
\text { of ez- } \\
\text { pansion }\end{array}$ & $\begin{array}{c}\text { Temperature range in degrees } \\
\text { centigrade }\end{array}$ & $\begin{array}{c}\text { Average } \\
\text { coefficients } \\
\text { of ex- } \\
\text { pansion }\end{array}$ \\
\hline-191 to $+16 \ldots \ldots \ldots \ldots \ldots \ldots \ldots$. & $10.1 \times 10^{-6}$ & 16 to $500 \ldots \ldots \ldots . . . .$. & 15. $2 \times 10^{-0}$ \\
\hline+16 to $250 . \ldots \ldots \ldots \ldots \ldots . . . . . . . .$. & 14.0 & 500 to $750 \ldots \ldots \ldots \ldots . . . . . . . . .$. & 17.6 \\
\hline 16 to $375 . \ldots \ldots \ldots \ldots \ldots \ldots . . . . . . .$. & 14.7 & 500 to $1000 \ldots \ldots \ldots \ldots \ldots \ldots . . . \ldots . . . .$. & 18.4 \\
\hline
\end{tabular}

In the present investigation determinations were made on the thermal expansion of to samples of commercial nickel from room temperature to about $600^{\circ} \mathrm{C}$. The nickel content varied from about 94 to 99 per cent. Five samples were hot-rolled, and the remaining five samples of corresponding compositions were hotrolled and annealed.

- Randall, Phys. Rev., 20, p. 85; 1905.

7 Henning, Annalen der Physik, 22 (fourth series), p. 63x; 1907. 
The following table gives the observations of one of the samples (S653). These results are represented graphically in the accompanying figure Fig. I, which shows a typical expansion curve:

TABLE 5.-Observations on Sample of Commercial Nickel

\begin{tabular}{|c|c|c|c|c|c|}
\hline Observation No. & $\begin{array}{l}\text { Tempera- } \\
\text { ture }\end{array}$ & $\Delta l^{*}$ & Observation No. & $\begin{array}{l}\text { Tempera- } \\
\text { ture }\end{array}$ & $\Delta l^{*}$ \\
\hline 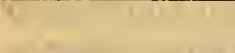 & & & & & \\
\hline $1, \ldots \ldots \ldots \ldots$ & 21.8 & $0 \times 10^{-6}$ & $10 \ldots$. & 348.1 & $4858 \times 10^{-6}$ \\
\hline $2 \ldots \ldots$ & 69.6 & 628 & $11 \ldots \ldots$ & 367.7 & 5180 \\
\hline $3 \ldots \ldots$ & 138.9 & 1591 & $12 \ldots \ldots$ & 383.4 & 5430 \\
\hline $4 \ldots \ldots \ldots$ & 212.2 & 2667 & $13 \ldots \ldots \ldots \ldots \ldots$ & 388.0 & 5509 \\
\hline $5 \ldots \ldots \ldots$ & 254.8 & 3327 & $14 \ldots \ldots \ldots \ldots$ & 504.4 & 7410 \\
\hline $6 \ldots \ldots \ldots \ldots \ldots$ & 300.8 & 4047 & $15 \ldots \ldots \ldots \ldots$ & 602.2 & 9063 \\
\hline $7 \ldots$ & 312.0 & 4239 & $16 \ldots \ldots \ldots \ldots$ & 447.0 & 6429 \\
\hline $8 \ldots \ldots$. & 326.8 & 4491 & $17 \ldots \ldots$ & 262.6 & 3381 \\
\hline $9 \ldots \ldots \ldots \ldots$ & 341.5 & 4756 & $18 \ldots \ldots \ldots$ & 30.8 & 80 \\
\hline
\end{tabular}

*Represents the change per unit length from the length at the initial temperature $21.8^{\circ} \mathrm{C}$.

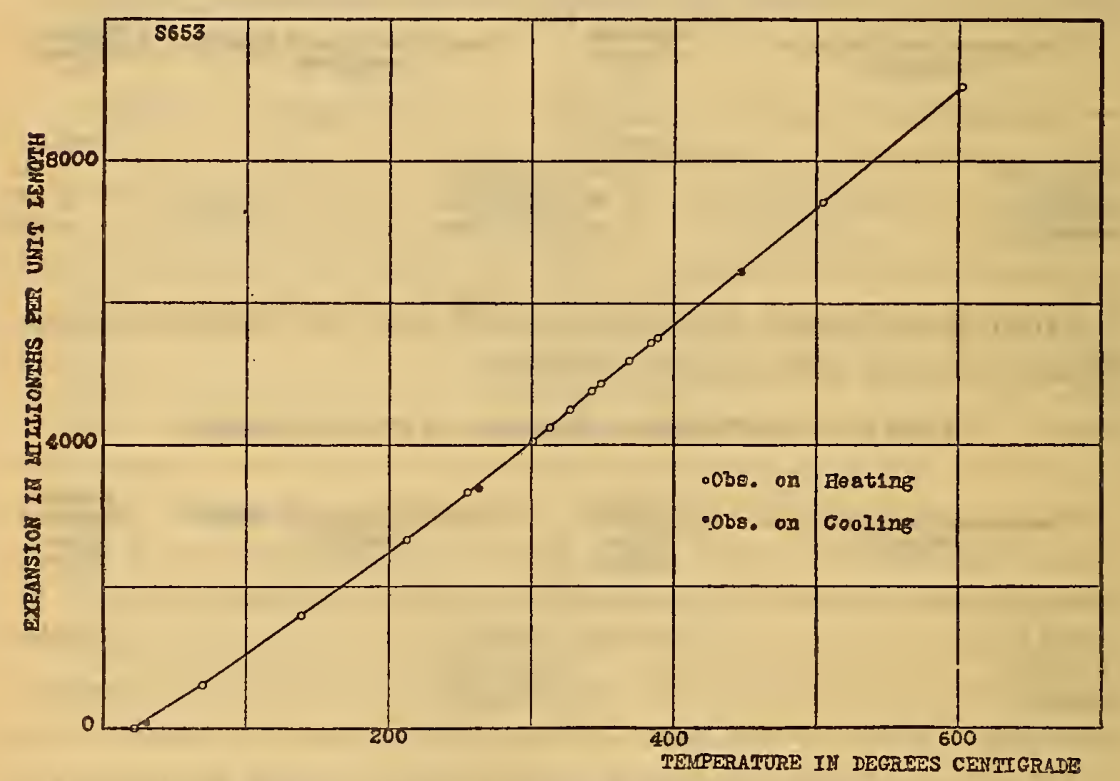

Frg. 1.-Thermal expansion of commercial nickel

A comparatively large number of observations were taken on each specimen between 300 and $400^{\circ} \mathrm{C}$ in an attempt to locate transformation regions, if any. No marked change was observed, but in most of the expansion curves of these samples a slight irregularity was perceptible in the region near $350^{\circ} \mathrm{C}$. This 
agrees with Harrison's ${ }^{8}$ statement that the true effect in the case of impure metals might be masked and modified by changes of a chemical nature.

The chemical compositions and the average coefficients of expansion for various temperature ranges are given in the following table:

TABLE 6.-Chemical Compositions and Average Coefficients of Expansion of Samples of Commercial Nickel

\begin{tabular}{|c|c|c|c|c|c|c|c|c|c|c|}
\hline \multirow{2}{*}{$\begin{array}{l}\text { Lab. } \\
\text { No. }\end{array}$} & \multirow{2}{*}{\multicolumn{2}{|c|}{ Material }} & \multicolumn{8}{|c|}{ Composition in per cent } \\
\hline & & & Ni & $\mathrm{Cu}$ & \multicolumn{2}{|c|}{$\mathrm{Fe}$} & $\mathbf{M n}$ & C & Si & $\mathbf{s}$ \\
\hline 5635 & \multirow{2}{*}{\multicolumn{2}{|c|}{$\begin{array}{l}\text { Hot-rolled, s. } 8 \text {-inch round............... } \\
\text { Same; annealed at } 1600^{\circ} \mathrm{F} \text { tor } 1 \text { hour. }\end{array}$}} & \multirow{2}{*}{99.06} & \multirow{2}{*}{0.12} & \multicolumn{2}{|c|}{0.37} & \multirow{2}{*}{0.19} & 0.12 & \multirow[t]{2}{*}{0.12} & \multirow[t]{2}{*}{0.027} \\
\hline S636 & & & & & & & & & & \\
\hline S652 & \multirow{2}{*}{\multicolumn{2}{|c|}{ Elot-rolled, 응-inch round, 10w carbon... }} & \multirow[t]{2}{*}{99.02} & \multirow{2}{*}{.12} & \multirow{2}{*}{\multicolumn{2}{|c|}{.37}} & \multirow[t]{2}{*}{.22} & .08 & \multirow[t]{2}{*}{.16} & \multirow{2}{*}{.020} \\
\hline S653 & & & & & & & & & & \\
\hline S654 & \multicolumn{2}{|c|}{ Hot-rolled, 8 -inch round, high carbon. } & \multirow{2}{*}{ 98. 76} & \multirow{2}{*}{.17} & \multirow{2}{*}{\multicolumn{2}{|c|}{.38}} & .18 & 22 & 26 & 020 \\
\hline S655 & Same; annealed at $1650^{\circ} \mathrm{F}$ for 1 & hour. & & & & & .10 & .28 & .20 & $.0<0$ \\
\hline S637 & Hot-rolled, $\frac{1}{t}$-inch round........ & ........ & 97.05 & 1 & 15 & 44 & 208 & 09 & 15 & 020 \\
\hline S638 & Same; annealed at $1600^{\circ} \mathrm{F}$ for 1 & hour.. & 300 & & & . & 2.0 & 然 & W & ota \\
\hline S639 & Hot-rolled; $\frac{1}{3}-$ inch round........ & & 94.21 & 1 & & 46 & 402 & 12 & 10 & 030 \\
\hline S640 & Same; annealed at $1600^{\circ} \mathrm{F}$ for 1 & hour.. & 27.21 & .1 & & .70 & $70=2$ & .18 & .20 & .00 \\
\hline 16 & & & & Average & e coeffici & cients of & 1 expansic & on $\times 10^{6}$ & & \\
\hline $\begin{array}{l}\text { Lap. } \\
\text { No. }\end{array}$ & Material & $\begin{array}{l}25 \text { to } \\
100^{\circ} \mathrm{C}\end{array}$ & $\begin{array}{l}100 \text { to } \\
200^{\circ} \mathrm{C}\end{array}$ & $\begin{array}{l}200 \text { to } \\
300^{\circ} \mathrm{C}\end{array}$ & 300 to & $500^{\circ} \mathrm{C}$ & $\begin{array}{ll}0 & 500 t^{t 0} \\
6 & 600^{\circ} \mathrm{C}\end{array}$ & $\begin{array}{r}25 \text { to } \\
300^{\circ} \mathrm{C}\end{array}$ & $\begin{array}{l}300 \text { to } \\
600^{\circ} \mathrm{C}\end{array}$ & $\begin{array}{r}25 \text { to } \\
600^{\circ} \mathrm{C}\end{array}$ \\
\hline S635 & Hot-rolled, a-inch round....... & 13. 2 & 14. 4 & 15.3 & 16.8 & 15.5 & 16. 9 & 14. 4 & 16. 4 & 15.4 \\
\hline S636 & Same; annealed at $1600^{\circ} \mathrm{F}$ for & & & & & & & & & \\
\hline & 1 hour....................... & 13. 3 & 14. 5 & 15.4 & 16. 4 & 16. 6 & 16. 3 & 14. 5 & 16. 5 & 15.5 \\
\hline S652 & Hot-rolled, $\frac{3}{8}$-inch round, low & & & & & & & & & \\
\hline & carbon & 12.9 & 14.5 & 15.4 & 16.9 & 16.5 & 16.8 & 14.4 & 16.7 & 15.6 \\
\hline S653 & Same; annealed at $1650^{\circ} \mathrm{F}$ for & & & & & & & & & \\
\hline & 1 hour...................... & 13. 3 & 14. 5 & 15.5 & 16. 7 & 16. 3 & 16. 9 & 14. 5 & 16.6 & 15.6 \\
\hline S654 & Hot-rolled, 急-inch round, high & & & & & & & & & \\
\hline & carbon....................... & 13.0 & 14. 2 & 15. 7 & 15.9 & 15. 7 & 14.4 & 14. 4 & 15.3 & 14.9 \\
\hline S655 & Same; annealed at $1650^{\circ} \mathrm{F}$ for & & & & & & & & & \\
\hline & 1 hour..................... & 13. 3 & 14. 2 & 15. 6 & 16. 3 & 16.2 & 16.3 & 14.5 & 16.3 & 15.4 \\
\hline S637 & Hot-rolled, $\frac{1}{2}$-inch round....... & 13. 1 & 13.5 & 14.8 & 17.2 & 16.6 & 17.1 & 13.8 & 17.0 & 15.5 \\
\hline S638 & Same; annealed at $1600^{\circ} \mathrm{F}$ for & & & & & & & & & \\
\hline & 1 hour.......................... & 13.5 & 14. 3 & 15.8 & 16.0 & 16.6 & $17 \cdot 3$ & 14.6 & 16. 6 & 157 \\
\hline S639 & Fot-rolled, $\frac{1}{3}$-inch round........ & 13.2 & 14. 1 & 15.4 & 15. 9 & 16. 7 & $17 \cdot 3$ & 14.3 & 16. 7 & 15.5 \\
\hline S640 & Same; annealed at $1600^{\circ} \mathrm{F}$ for & & & & & & & & & \\
\hline & 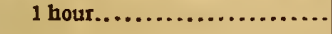 & 13.3 & 14. 1 & 15.4 & 15. 9 & 16.6 & 17.6 & 14. 3 & 16. 7 & 15. 6 \\
\hline
\end{tabular}

From an examination of the preceding table it is apparent that the annealing of the hot-rolled samples in most cases caused a slight increase in the coefficients. The average coefficients

\footnotetext{
${ }^{8}$ Harrison, Phil. Mag., 7 (sixth series), D. 626; 1904.
} $62786^{\circ}-22-2$ 
between 25 and $300^{\circ}$ for the samples containing 98.76 to 99.06 per cent nickel are $14.4 \times 10^{-6}$ for the hot-rolled and $14.5 \times 10^{-6}$ for the annealed specimens. For the range from 25 to $600^{\circ} \mathrm{C}$, the coefficients of the five hot-rolled samples vary from $14.9 \times 10^{-6}$ to $15.6 \times 10^{-6}$, and for the five annealed specimens from $15.4 \times 10^{-6}$ to $15.7 \times 10^{-6}$. These coefficients are considerably greater than those of most of the porcelains described in Scientific Papers of the Bureau of Standards, No. 352 .

The average coefficients of expansion of the 10 samples of nickel vary from $12.9 \times 10^{-6}$ to $13.5 \times 10^{-6}$ for the range 25 to $100^{\circ} \mathrm{C}$. These coefficients are approximately ro or 20 per cent greater than those of ordinary steel for the same range.

On cooling from the maximum temperature (about $600^{\circ} \mathrm{C}$ ) to room temperature the observations were generally slightly below the heating curve, so that after the thermal expansion tests the specimens were shorter than before these tests. Holborn and Day ${ }^{\circ}$ also found a diminution in the length of a rod of nickel after each heating and cooling. Harrison, ${ }^{10}$ however, found that in every case nickel wire returned to its original length after heating.

The following table gives the changes in length from the original lengths after the thermal expansion tests. The minus $(-)$ sign indicates a decrease in length:

TABLE 7.-Changes in Length Due to Heat Treatment Received During Test

\begin{tabular}{|c|c|c|c|}
\hline Laboratory number & $\begin{array}{c}\text { Change in } \\
\text { length after } \\
\text { test }\end{array}$ & Laboratory number & $\begin{array}{l}\text { Change in } \\
\text { length after } \\
\text { test }\end{array}$ \\
\hline \$635.... & $\begin{array}{l}\text { Per cent } \\
-0.004\end{array}$ & S655................................ & $\begin{array}{l}\text { Per cent } \\
-.018\end{array}$ \\
\hline S636............ & -.013 & S637................................. & -.020 \\
\hline S652....... & -.004 & 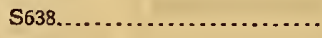 & -.004 \\
\hline S653...... & -.004 & S639....................... & -.003 \\
\hline S654........ & $a-.064$ & 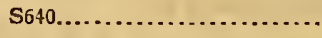 & .000 \\
\hline
\end{tabular}

$a$ At any given temperature above room temperature the variation between the heating and cooling curves did not exceed this value.

\section{MONEL METAL}

Monel metal is a natural alloy of the approximate formula: Nickel, 67 per cent; copper, 28 per cent; and the remaining 5 per cent made up of iron, manganese, silicon, etc.

\footnotetext{
9 Holborn and Day, Annalen der Physik, 39 (fourth series), p. r04; rgor.

${ }^{10}$ Harrison, Phil. Mag., 7 (sixth series), p. 626; 1904.
} 
Measurements were made on the thermal expansion of ro samples of monel metal from room temperature to about $600^{\circ} \mathrm{C}$. Two samples were cast, and three were hot-rolled. The remaining five specimens of corresponding compositions and treatments received additional heat treatment; that is, they were annealed.

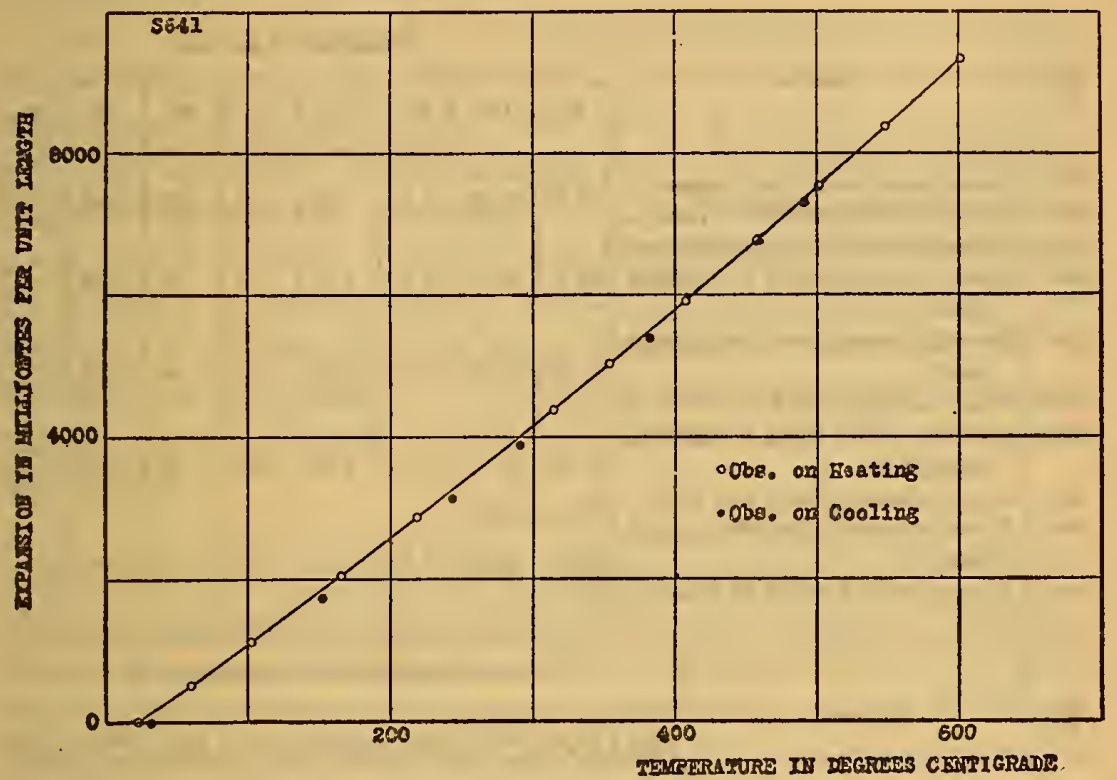

Fig. 2.-Thermal expansion of monel metal

A typical expansion curve (S64I) is shown in Fig. 2, and the observations from which it was obtained are given in Table 8.

TABLE 8.-Observations on Expansion of a Sample of Monel Metal

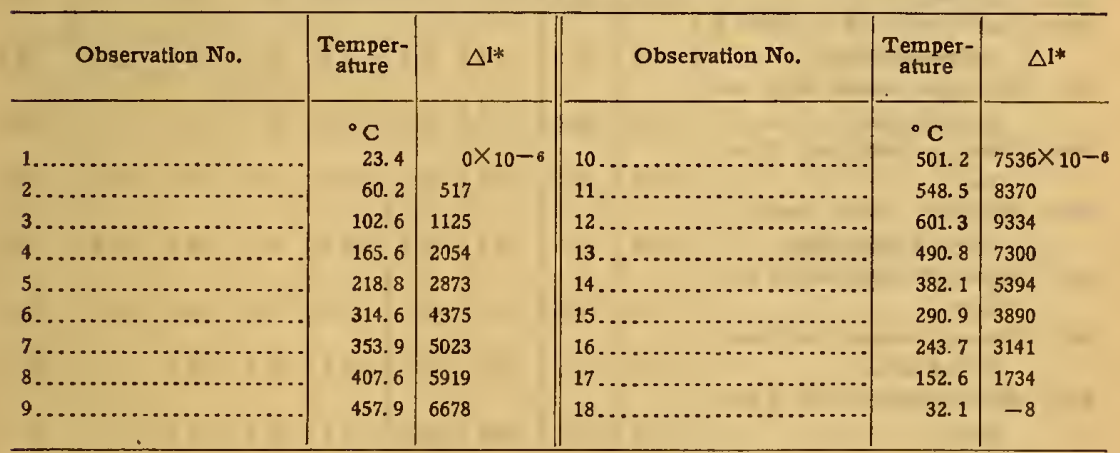

* $\Delta \mathrm{l}$ represents the change per unit length from the length at the initial temperature $23.4^{\circ} \mathrm{C}$.

The expansion curves on heating were found to be fairly regular. On cooling the observations were slightly below the heating curves in most cases. 
The chemical compositions and the average coefficients of expansion for various temperature ranges are given in the following table:

TABLE 9.-Chemical Compositions and Average Coefficients of Expansion of Samples of Monel Metal

\begin{tabular}{|c|c|c|c|c|c|c|c|c|c|c|}
\hline \multirow{2}{*}{$\begin{array}{l}\text { Lab. } \\
\text { No. }\end{array}$} & \multirow{2}{*}{\multicolumn{2}{|c|}{ Materlal }} & \multicolumn{8}{|c|}{ Composition in per cent } \\
\hline & & & $\mathrm{Ni}$ & $\mathrm{Cu}$ & $\mathrm{Fe}$ & $\mathbf{M n}$ & C & S1 & $\mathbf{S}$ & $\mathbf{P b}$ \\
\hline S648 & \multirow{2}{*}{\multicolumn{2}{|c|}{$\begin{array}{l}\text { Leaded monel, cast } 8 / 8 \text { inch square.... } \\
\text { Same; annealed } 1650^{\circ} \mathrm{F} \text { for } 1 \text { hour .... }\end{array}$}} & & & & & & & & \\
\hline S649 & & & 60.05 & 32.46 & 2.21 & 2.00 & 0.15 & 0.87 & 0.035 & 2. 22 \\
\hline S663 & \multicolumn{2}{|c|}{ Cast nonleaded monel, $3 / 8$ lnch square . } & & & & & & & & \\
\hline S664 & \multicolumn{2}{|c|}{ 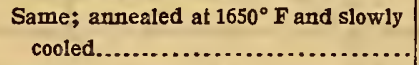 } & 66.18 & 28.42 & 2.37 & 2.10 & .18 & .70 & .038 & \\
\hline S641 & \multicolumn{2}{|c|}{ 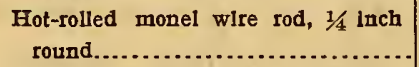 } & 66.58 & 29.57 & 1.79 & 1.78 & .15 & .09 & .030 & \\
\hline S688 & \multirow{3}{*}{\multicolumn{2}{|c|}{ 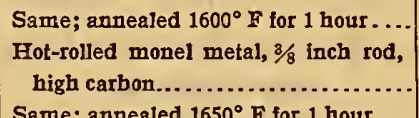 }} & & & & & & & & \\
\hline S650a & & & 67.32 & 28. 73 & 1.74 & 1.66 & b. 31 & .19 & .035 & \\
\hline S651 & & & & 20.0 & (2) & (2) & . & 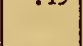 & . & \\
\hline S661 & \multirow{2}{*}{\multicolumn{2}{|c|}{$\begin{array}{r}\text { Hot-rolled monel } 1 / 8 \text { Inch sheet, } 3 / 8 \text { inch } \\
\text { wide............................. } \\
\text { Same; annealed } 1600^{\circ} \mathrm{F} \text { for } 1 \text { hour.... }\end{array}$}} & 68.87 & 29.03 & 1.60 & 0.18 & .13 & .15 & .027 & \\
\hline S662 & & & & & & & & & & \\
\hline \multirow[b]{2}{*}{$\begin{array}{l}\text { Lab. } \\
\text { No. }\end{array}$} & \multicolumn{10}{|c|}{ Average coefficlents of expansion $\times 10^{5}$} \\
\hline & Material & $\begin{array}{c}25 \text { to } \\
100^{\circ} \mathrm{C}\end{array}$ & $\begin{array}{l}100 \text { to } \\
200^{\circ} \mathrm{C}\end{array}$ & 200 to & $\begin{array}{l}300 \text { to } \\
400^{\circ} \mathrm{C}\end{array}$ & 400 to & $\begin{array}{l}500 \text { to } \\
600^{\circ} \mathrm{C}\end{array}$ & 25 to & $\begin{array}{l}300 \text { to } \\
600^{\circ} \mathrm{C}\end{array}$ & $\begin{array}{c}25 \text { to } \\
600^{\circ} \mathrm{C}\end{array}$ \\
\hline S648 & 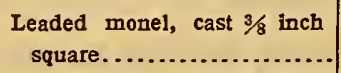 & 13.9 & 15.0 & 15.8 & 16.8 & 17.7 & 20.6 & 15.0 & 18.4 & 16.7 \\
\hline S649 & Same; annealed $1650^{\circ} \mathrm{F}$ lor 1 & & & & & & & & & \\
\hline & hour............... & 14. 3 & 15.0 & 15. 7 & 16. 7 & 18.1 & 18.3 & 15.1 & 17.7 & 16.5 \\
\hline S663 & $\begin{array}{c}\text { Cast nonleaded monel, } 3 / 8 \\
\text { lnch aquare................ }\end{array}$ & 13.7 & 15.1 & 15.7 & 16.6 & 17.7 & 18.5 & 15.0 & 17.6 & 16.4 \\
\hline S664 & $\begin{array}{l}\text { Same; annealed at } 1650^{\circ} \mathrm{F} \\
\text { and slowly cooled............. }\end{array}$ & 13.9 & 15.0 & 15.7 & 16.6 & 17.8 & 18.7 & 15.0 & 17.7 & 16.4 \\
\hline S641 & $\begin{array}{l}\text { Hot-rolled monel wlre rod, } \\
1 / 4 \text { inch round.............. }\end{array}$ & 14.2 & 14.9 & 15.5 & 16.7 & 17.0 & 18.1 & 14.9 & 17.3 & 16.1 \\
\hline S688 & 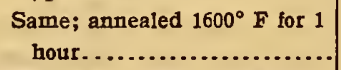 & 14.3 & 15.3 & 15.8 & 16.5 & 17.4 & 17.7 & 15.2 & 17.2 & 16.2 \\
\hline S650a & $\begin{array}{r}\text { Hot-rolled monel metal, } 3 / 8 \\
\text { lnch rod, high carbon......... }\end{array}$ & 14.5 & 15.1 & 15.9 & 16.4 & 17.1 & 16.2 & 15.2 & 16.6 & 15.9 \\
\hline S651 & 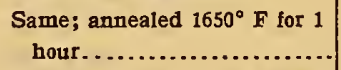 & 14.3 & 15.0 & 15.8 & 16.5 & 17.4 & 17.7 & 15.1 & 17.2 & 16.2 \\
\hline S661 & $\begin{array}{r}\text { Hot-rolled mone } 1 / 8 \text { inch sheet, } \\
3 / 8 \text { inch wlde................ }\end{array}$ & 14.2 & 14. 7 & 15.6 & 16.4 & 17.6 & 17.9 & 14.9 & 17.3 & 16. 2 \\
\hline S662 & $\begin{array}{l}\text { Same; annealed } 1600^{\circ} \mathrm{F} \text { for } 1 \\
\text { hour.............................. }\end{array}$ & 14.0 & 15.0 & 15.9 & 16.4 & 17.3 & 18. 1 & 15.1 & 17.3 & 16.2 \\
\hline
\end{tabular}

$a$ The coefficients given for this sample are the average values obtained on two duplicate samples.

Graphitic carbon $=0.15$. 
It is interesting to note that the average coefficients for the range from 25 to $300^{\circ} \mathrm{C}$ are all practically equal. Above $300^{\circ}$ there are some marked differences. For example, the coefficients of S648 and S649 between 500 and $600^{\circ} \mathrm{C}$ differ by $2.3 \times 10^{-6}$. In most cases the coefficients of the annealed and unannealed samples are equal or nearly so.

From a comparison of the average coefficients for the entire temperature range from 25 to $600^{\circ} \mathrm{C}$, it is seen that the coefficients of the cast alloys are greater than those of the hot-rolled alloys, and that the leaded monel samples have the greatest coefficients.

The coefficients of expansion of monel metal are larger than those of the samples of nickel described in the previous section. In addition to nickel monel metal contains about 30 per cent copper, which element has larger coefficients than those of the nickel or monel samples. The copper constituent, therefore, evidently raises the value of the coefficient of the alloy of copper and nickel.

\section{STELLITE}

This subsection includes five samples of stellite, which alloy is usually composed of cobalt, chromium, and tungsten. The alloy is sometimes modified by the addition of iron or by the substitution of molybdenum for tungsten and possibly nickel for cobalt. The discovery and other features connected with the application of this alloy have been described by the inventor. ${ }^{11}$

The approximate chemical compositions of the samples and the average coefficients of expansion for various temperature ranges are given in the following table:

${ }^{11}$ Elwood Haynes, Proc. Eng. Soc. Western Pennsylvania, 35, p. 467; Feb., I920, and American Machin ist, 53, No. 4, p. I7r; July 22, I920.

$62786^{\circ}-22-3$ 
TABLE 10.-Approximate Chemical Compositions and Average Coefficients of Expansion of Samples of Stellite

\begin{tabular}{|c|c|c|c|c|c|c|c|c|}
\hline \multirow[t]{2}{*}{$\begin{array}{l}\text { Lab. } \\
\text { No. }\end{array}$} & \multirow[t]{2}{*}{ Material } & \multicolumn{5}{|c|}{ Approximate composition in per cent } & \multicolumn{2}{|c|}{$\begin{array}{l}\text { Average co- } \\
\text { efficients of } \\
\text { expansion } \times 10^{\circ} \\
\text { in various } \\
\text { ranges of } \\
\text { temperature }\end{array}$} \\
\hline & & Co & $\mathrm{Cr}$ & W & C & Fe & $\begin{array}{l}20 \text { to } \\
100^{\circ} \mathrm{C}\end{array}$ & $200^{\circ} \mathrm{C}$ \\
\hline S521 & Festel metal $a \ldots$ & $b 22.5$ & 21.2 & & 0.7 & 55.3 & $\left\{\begin{array}{r}15.6 \\
c 12.5\end{array}\right.$ & $\begin{array}{l}16.7 \\
13.0\end{array}$ \\
\hline S534 & Stellite, soft malleable.... & 80 & 20 & & ... & ....... & 14.1 & 15.1 \\
\hline S535 & Stellite, hard malleable.............. & 55 & 40 & 3 & 2 & ........ & 13.4 & 15.2 \\
\hline S537 & Stellite, hard malleable, hammered... & 55 & 40 & 3 & 2 & ........ & 12.2 & 13.1 \\
\hline S536 & Stellite No. $2 \ldots \ldots \ldots \ldots \ldots \ldots \ldots \ldots \ldots \ldots \ldots$ & 55 & 35 & 10 & & -...... & 11.0 & 12.3 \\
\hline \multirow{2}{*}{$\begin{array}{l}\text { Lab. } \\
\text { No. }\end{array}$} & \multirow{2}{*}{ Material } & \multicolumn{7}{|c|}{$\begin{array}{l}\text { Average coefficients of expansion } \times 10^{6} \text { in various ranges } \\
\text { of temperature }\end{array}$} \\
\hline & & $\begin{array}{l}200 \text { to } \\
300^{\circ} \mathrm{C}\end{array}$ & 300 to & $\begin{array}{l}400 \text { to } \\
500^{\circ} \mathrm{C}\end{array}$ & $\begin{array}{l}500 \text { to } \\
600^{\circ} \mathrm{C}\end{array}$ & $\begin{array}{l}20 \text { to } \\
300^{\circ} \mathrm{C}\end{array}$ & $\begin{array}{l}300 \text { to } \\
600^{\circ} \mathrm{C}\end{array}$ & $\begin{array}{l}20 \text { to } \\
600^{\circ} \mathrm{C}\end{array}$ \\
\hline \multirow{2}{*}{ \$521 } & \multirow{2}{*}{ Festel metal $a$.. } & 17.6 & 17.8 & 17.6 & 17.0 & 16. 7 & 17.5 & d 17.1 \\
\hline & & 13.8 & 14. 8 & 15. 7 & ......... & 13. 1 & & \\
\hline S534 & Stellite, soft malleable...... & 16.2 & 15. 9 & 16.0 & 18. 9 & 15.2 & 16.9 & 16. 1 \\
\hline S535 & Stellite, hard malleable............. & 16. 0 & 16. 3 & 17.5 & 20.2 & 15.0 & 18.0 & 16.5 \\
\hline S537 & Stellite, hard malleable, hammered. . & 14. 0 & 14. 3 & 15.4 & 17.9 & 13. 2 & 15.8 & 14. 6 \\
\hline S536 & Stellite No. 2...................... & 13.6 & 13. 8 & 13.3 & 16.9 & 12.4 & 14. 7 & e 13.6 \\
\hline
\end{tabular}

a According to the inventor "festel metal is somewhat indefinite in its composition. The name was derived from $\mathrm{Fe}$, the symbol for iron, prefixed to the first syllable of stellite, and means stellite with more or less iron added. Festel metal is a mixture of cobalt, chromium, and iron, and generally contains from ro to 25 per cent of the latter, but may contain as high as 40 or even 50 per cent."

$b$ The chemical composition of this sample of festel metal was determined by J. A. Scherrer of this Bureau. The sample also contains o.I per cent silicon.

$c$ Values given on this horizontal line were obtained on a second test.

d Average coefficient of expansion between 600 and $900^{\circ} \mathrm{C}$, was $\times 9.7 \times 10^{-6}$.

e After this test stellite No. 2 was cooled to about $-100^{\circ} \mathrm{C}$; average coefficient of contraction from ig to $-94^{\circ} \mathrm{C}$ was $10.2 \times 10^{-6}$.

Figs. 3 to 6 show the expansion curves of four samples of stellite $\left(\mathrm{S}_{534}, 535,537\right.$, and 536$)$ from room temperature to about $600^{\circ} \mathrm{C}$. After these tests one of the specimens $\left(\mathrm{S}_{536}\right)$ was cooled from room temperature to about $-100^{\circ} \mathrm{C}$, and the results were represented graphically in Fig. 7.

From an examination of the curves and the average coefficients of expansion it is evident that the expansion curves in most cases are irregular in the region between 300 and $500^{\circ} \mathrm{C}$. For example, in the case of the soft malleable stellite $\left(\mathrm{S}_{534}\right)$, the rate of expansion increases regularly with temperature up to $300^{\circ} \mathrm{C}$ and then decreases to a nearly constant value over the range from 300 to $500^{\circ} \mathrm{C}$. At the latter temperature the average rate of expansion again increases rapidly from 500 to $600^{\circ} \mathrm{C}$. 


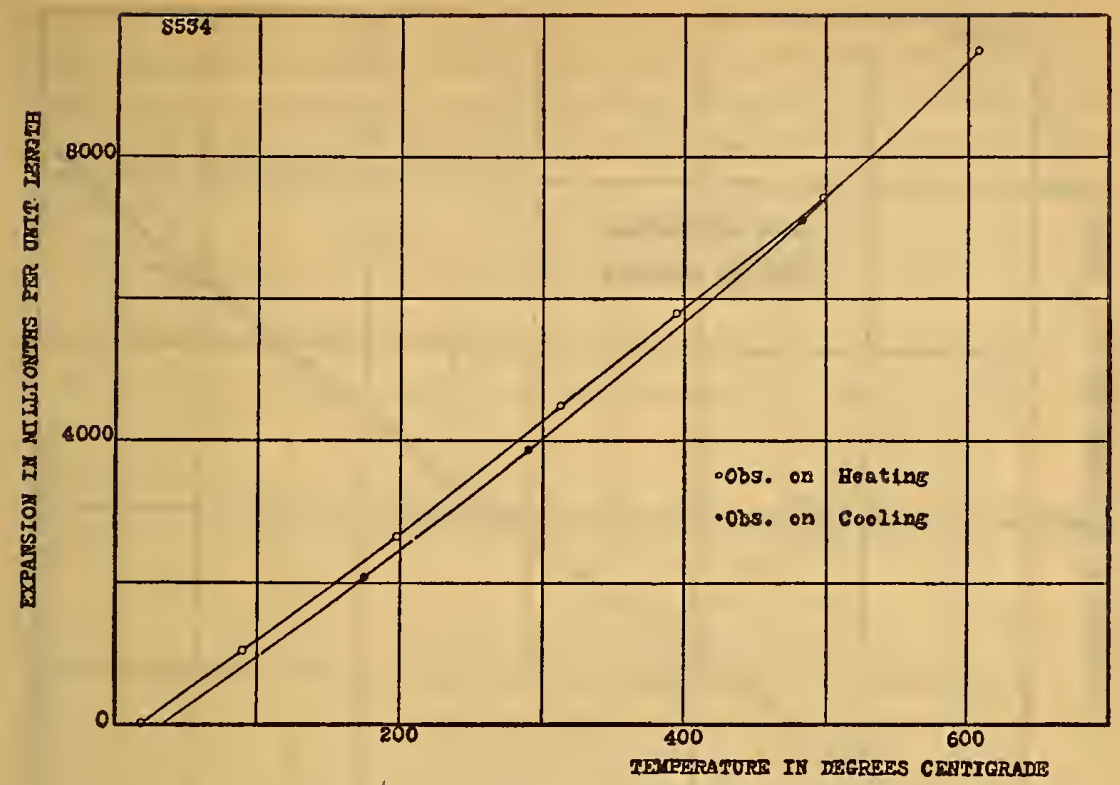

FIG. 3.-Thermal expansion of soft malleable stellite

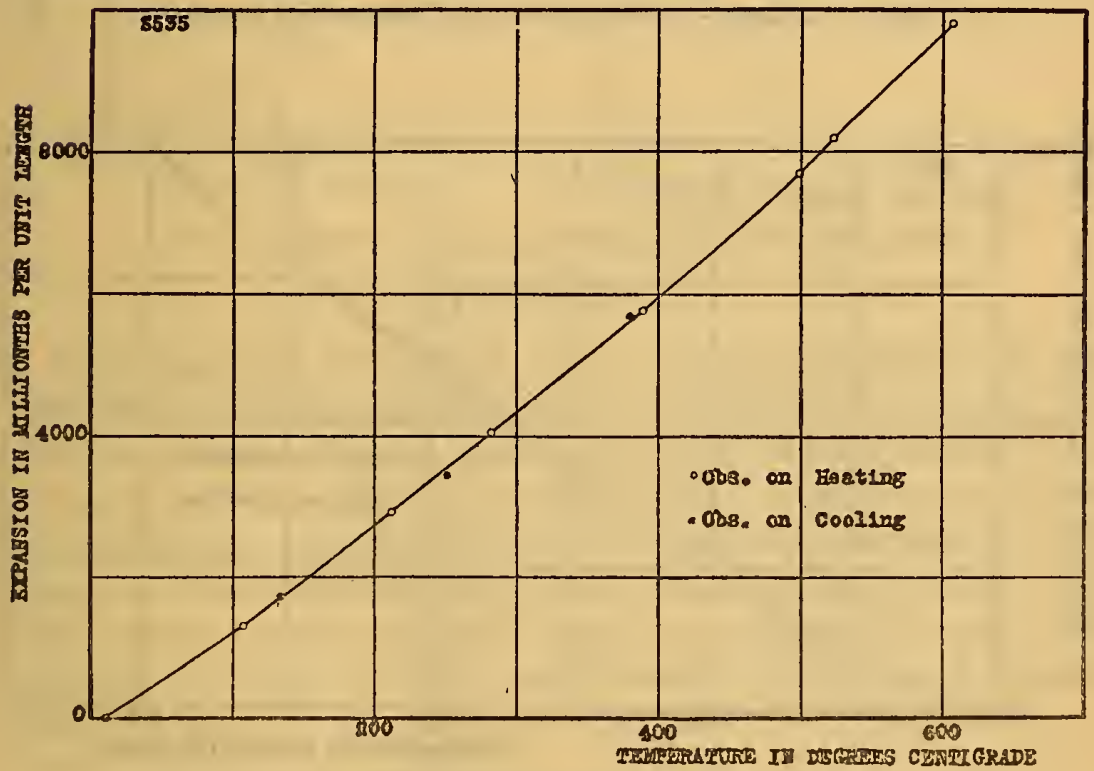

FrG. 4.-Thermal expansion of hard malleable stellite 


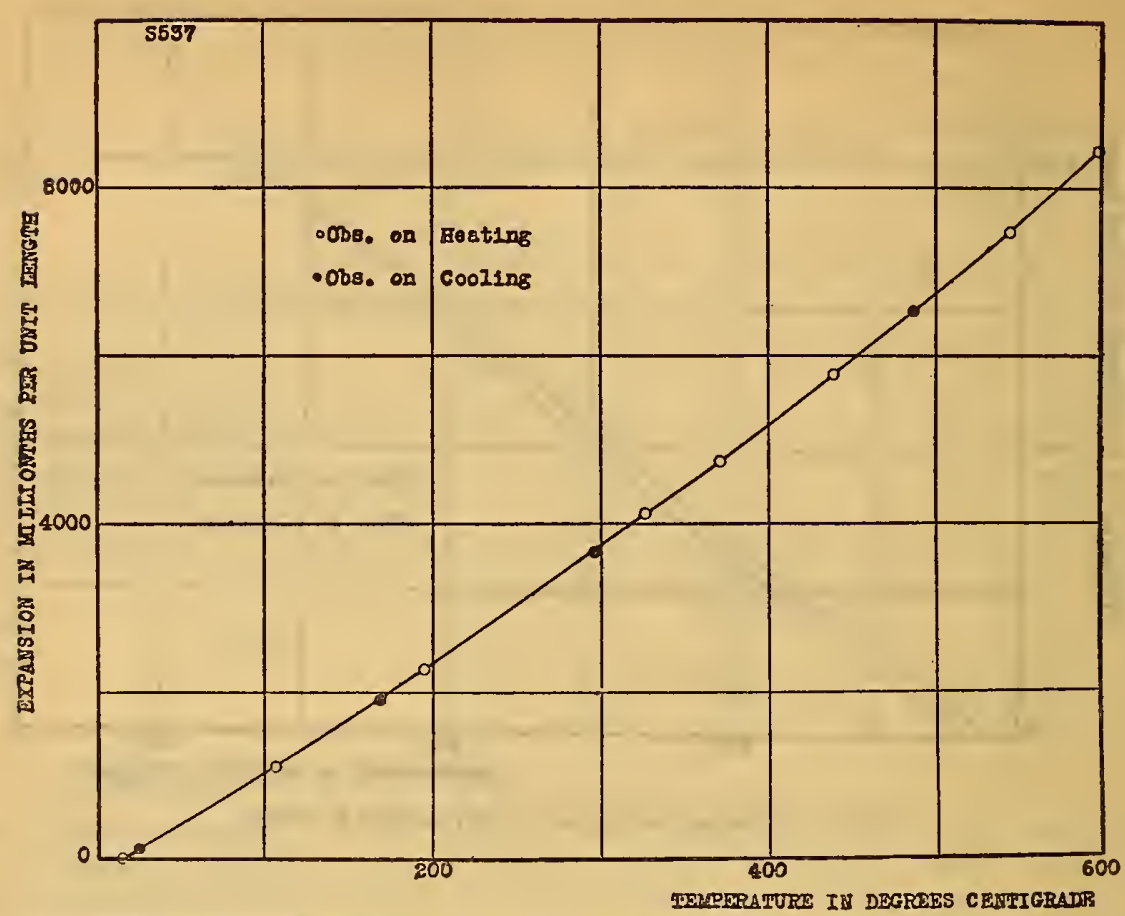

Fig. 5.-Thermal expansion of hard malleable stellite, hammered

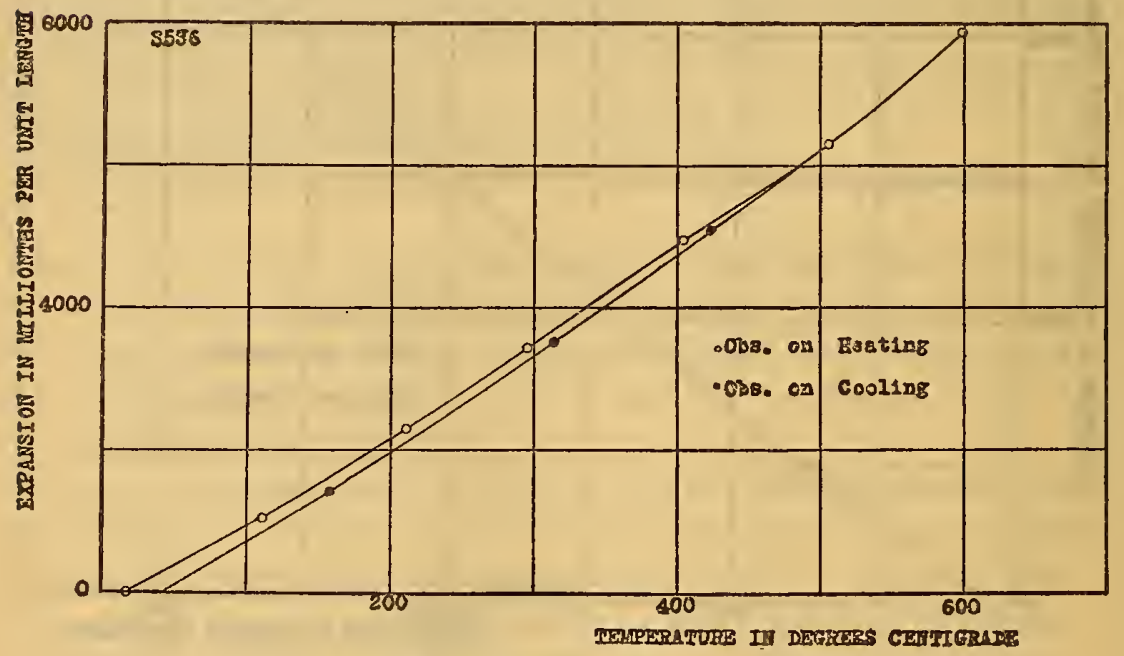

FIG. 6.-Thermal expansion of stellite No. 2 
The stellite containing ro per cent tungsten $\left(\mathrm{S}_{53} 6\right)$ has the smallest coefficients of expansion of any sample investigated. The hammered stellite $\left(\mathrm{S}_{537}\right)$ has smaller coefficients than the unhammered sample of corresponding composition, which indicates that hammering may lower the values of the coefficients of expansion.

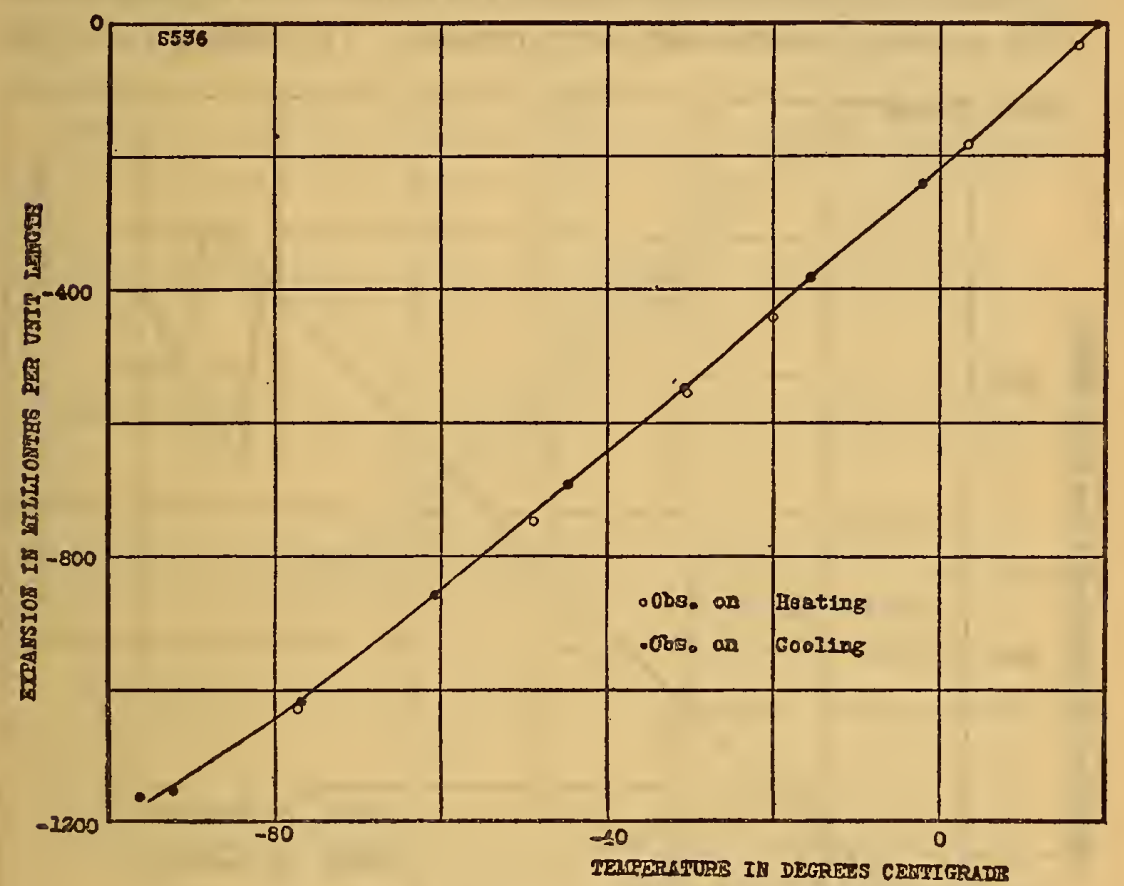

FIG. 7.-Thermal expansion of stellite No. 2 at low temperatures

\section{STAINLESS STEEL}

Determinations were made on the thermal expansion of two samples of stainless steel from room temperature to about $900^{\circ} \mathrm{C}$. The composition of these specimens was as follows: Carbon, 0.30 per cent; silicon, o. I I per cent; manganese, o. 8 per cent; sulphur, o.o I I per cent; phosphorus, o.O2O per cent; and chromium, I3.IO per cent. One of the samples ( 5620 ). was electrically melted, cast into ingots, hammer cogged, finished on rolling mill, and then annealed at $1400^{\circ} \mathrm{F}$. The other sample (S680) was hardened (and not drawn). Its hardness number ${ }^{12}$ was found to be 77.7 (scleroscope).

12 Determined by W. B. Topping, of this Bureau. 
The expansion curves of the two steels are shown in Figs. 8 and 9. On heating, both samples indicated critical regions which extended from approximately 825 to approximately $855^{\circ} \mathrm{C}$. The transformation point of ordinary steel usually occurs at lower temperatures. For the two samples of stainless steel the transformation point on cooling occurred at approximately $800^{\circ} \mathrm{C}$.

$\mathrm{Up}$ to the transformation regions the heating and cooling curves of the annealed sample are fairly regular. The cooling curve lies

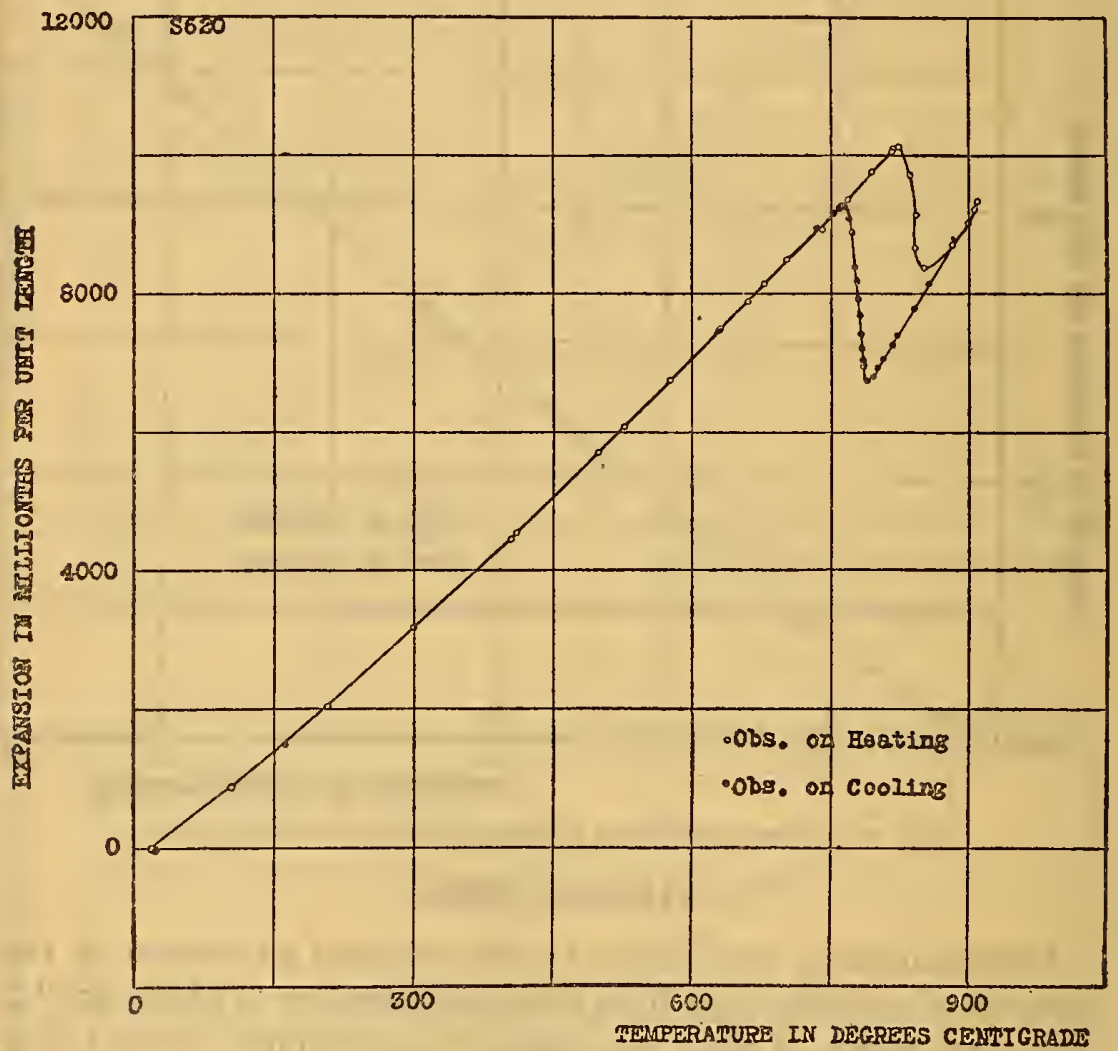

FIG. 8.-Thermal expansion of annealed stainless steel

slightly below the heating curve, and at the end of the test the sample was very slightly shorter than before the test, which indicates that this specimen did not suffer any great permanent deformation due to the heat treatment incident to the test.

In the case of the hardened steel the curve is irregular between 200 and $400^{\circ} \mathrm{C}$, where the strains produced in hardening were probably released. Above $400^{\circ}$ the sample behaved like the annealed specimen. This property is in agreement with the samples of carbon steel recently studied. (Complete data on these 
steels will be available at a future date.) The cooling curve lies below the heating curve, and at the end of the test the sample was 0.088 per cent shorter than before the test. The cooling curve of the hardened sample is fairly regular and in close agreement with the curve of the annealed sample, as will be shown later from a comparison of the coefficients.

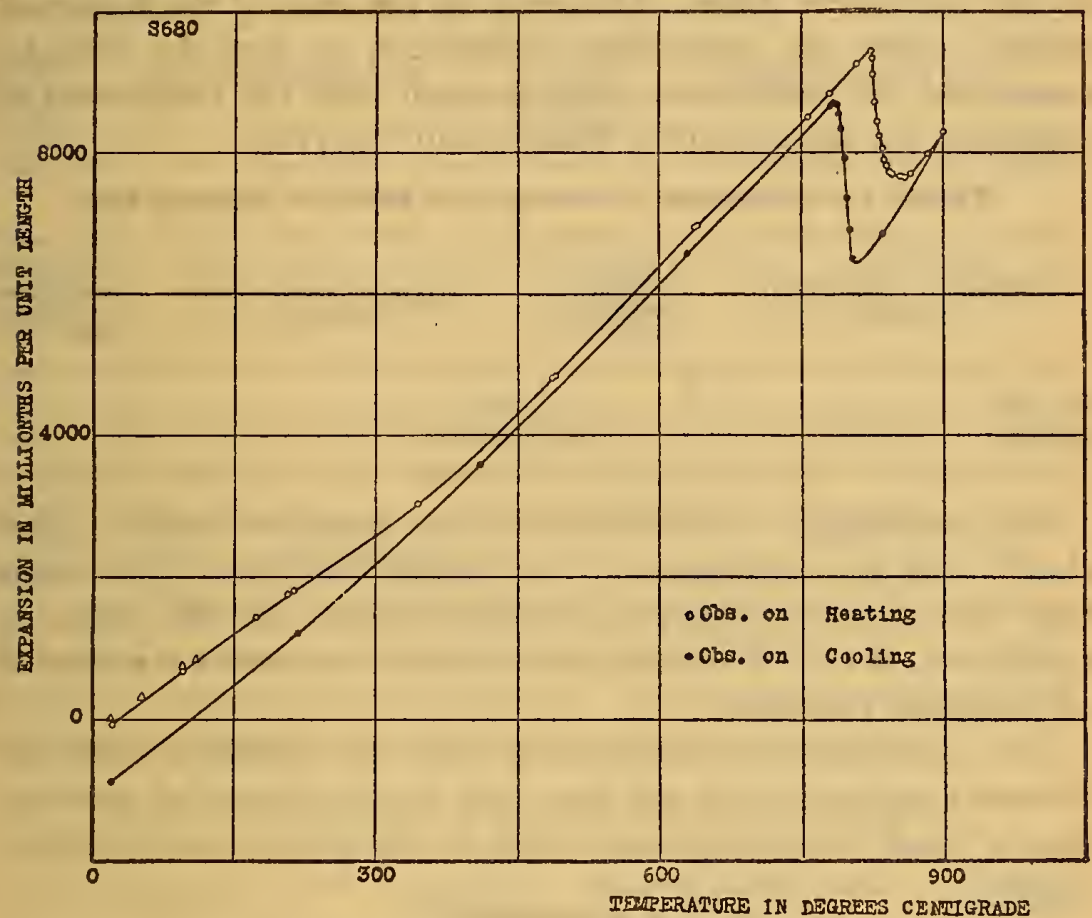

Fig. 9.-Thermal expansion of hardened stainless steel

The coefficients of expansion of the two samples of stainless steel for various temperature ranges are given in the following tables:

TABLE 11.-Coefficients of Expansion of Stainless Steel

\begin{tabular}{|c|c|c|c|c|c|}
\hline \multirow{2}{*}{$\begin{array}{l}\text { Temperature range in degrees } \\
\text { centigrade }\end{array}$} & \multicolumn{2}{|c|}{$\begin{array}{l}\text { Average coefficients } \\
\text { of expansion } \times 10^{6}\end{array}$} & \multirow{2}{*}{$\begin{array}{c}\text { Temperature range in degrees } \\
\text { centigrade }\end{array}$} & \multicolumn{2}{|c|}{$\begin{array}{l}\text { Average coefficients } \\
\text { of expanslon } \times 10^{8}\end{array}$} \\
\hline & $\begin{array}{l}\text { Hard- } \\
\text { ened }\end{array}$ & $\underset{\text { nealed }}{\text { An }}$ & & $\begin{array}{l}\text { Hard- } \\
\text { ened }\end{array}$ & $\begin{array}{l}\text { An- } \\
\text { nealed }\end{array}$ \\
\hline 20 to $100 \ldots$ & $\begin{array}{r}a 9.6 \\
9.9\end{array}$ & 10.3 & $\begin{array}{l}400 \text { to } 600 \ldots \ldots \ldots \ldots \ldots . . . \\
600 \text { to } 800 \ldots \ldots \ldots \ldots \ldots\end{array}$ & $\begin{array}{l}13.8 \\
13.4\end{array}$ & $\begin{array}{l}13.3 \\
13.6\end{array}$ \\
\hline 20 to $200 \ldots \ldots \ldots . .$. & 9.8 & 10.7 & 20 to $600 \ldots \ldots \ldots \ldots$. & 11.2 & 12.1 \\
\hline 200 to $400 \ldots \ldots \ldots . . .$. & 9.9 & 12.3 & & & \\
\hline
\end{tabular}

$a$ Value on first heating to about $100^{\circ} \mathrm{C}$. After the sample was cooled to room temperature the test was carried to $900^{\circ} \mathrm{C}$. First heating plotted at triangles. (See Fig.9.) 
Up to $400^{\circ} \mathrm{C}$ the coefficients of expansion of the annealed sample are appreciably larger than those of the hardened sample. Annealing, therefore, caused an increase in the values of the coefficients of the hardened sample up to $400^{\circ} \mathrm{C}$.

Since the cooling curve of the annealed sample is only slightly below the heating curve, the coefficients on cooling and on heating do not materially differ. However, in the case of the hardened sample, there are appreciable differences, as may be seen by comparing the coefficients of contraction with the coefficients of expansion for corresponding temperature intervals.

TABLE 12.-Coefficients of Contraction of Hardened Stainless Steel

\begin{tabular}{|c|c|c|c|}
\hline $\begin{array}{c}\text { Temperature range in degrees } \\
\text { centigrade }\end{array}$ & $\begin{array}{c}\text { Average } \\
\text { coefficients } \\
\text { of contrac- } \\
\text { tion } \times 10^{6}\end{array}$ & $\begin{array}{c}\text { Temperature range in degrees } \\
\text { centigrade }\end{array}$ & $\begin{array}{l}\text { Average } \\
\text { coefficiento } \\
\text { of contrac- } \\
\text { tion } \times 10^{6}\end{array}$ \\
\hline 600 to $400 \ldots \ldots \ldots$. & 13. 6 & 200 to $20 \ldots \ldots \ldots$ & 10.5 \\
\hline 400 to $200 \ldots \ldots \ldots . . . . . . . . .$. & 12. 2 & 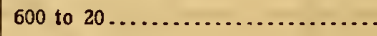 & 12. 1 \\
\hline
\end{tabular}

The coefficients of contraction of the hardened sample agree closely with the coefficients of the annealed sample. This means that the former specimen on cooling behaved like the annealed sample, as, in fact, it should, since the heat treatment constituted an annealing operation.

The coefficients of expansion of both the hardened and the annealed stainless steel are less than the coefficient of ordinary iron or steel, which is probably due to the large amount of chromium.

\section{ALUMINUM}

Although bearing only a slight similarity or relation to the previous nontarnishing alloys or metals reported in this paper, it is desired to record the expansion of exceptionally pure aluminum.

Some years ago Dr. R. Seligman ${ }^{13}$ cited an example of the importance of accurate information on the thermal expansion of aluminum. "I was recently called in to examine an aluminum vacuum pan made on the Continent for a firm of oil distillers, about Io feet long, which had collapsed. I found that the collapse was due to insufficient allowance for the difference in expansion of aluminum and iron under the influence of high temperature."

A number of investigations on the expansion of aluminum have been undertaken by various observers. Some of the results are given in this section. 
In 1901 Dittenberger ${ }^{14}$ made a number of determinations on a 0.5 -meter rod of pure material obtained from the Allgemeinen Elektrizitäts-Gesellschaft (of Germany). The table gives the average coefficients of expansion which were computed from his data.

TABLE 13.-Coefficients of Expansion of Aluminum (Dittenberger)

\begin{tabular}{|c|c|c|c|c|c|c|c|c|c|c|c|}
\hline \multirow{2}{*}{$\begin{array}{l}\text { Temper } \\
\text { ature in- } \\
\text { terval in } \\
\text { degrees } \\
\text { centi- } \\
\text { grade }\end{array}$} & \multicolumn{5}{|c|}{ Average coefficients $\times 10^{6}$} & \multirow{2}{*}{$\begin{array}{c}\text { Temper- } \\
\text { ature in- } \\
\text { terval in } \\
\text { degrees } \\
\text { centi- } \\
\text { grade }\end{array}$} & \multicolumn{5}{|c|}{ Average coefficients $\times 10^{6}$} \\
\hline & Nov. 11 & Nov. 12 & Nov.13 & Nov. 29 & Nov. 30 & & Nov. 11 & Nov. 12 & Nov. 13 & Nov. 29 & Nov. 30 \\
\hline $0-250 \ldots$ & & 23. 7 & 23. 6 & 23.8 & & $0-375 \ldots$ & 25.4 & 25.4 & 25.4 & & \\
\hline $250-375$ & & 28.8 & 28.8 & ...... & & $0-500 \ldots$ & 26.2 & 26. 2 & 26.1 & 26.5 & ..... \\
\hline $250-500 .$. & 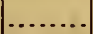 & & ....... & 29.2 & & $0-610 \ldots$ & & & & & 28. 0 \\
\hline $375-500 .$. & 28.6 & 28.5 & 28.3 & $\ldots \ldots$ & & & & & & & \\
\hline
\end{tabular}

He states that the expansion of aluminum can not be represented by a quadratic equation, especially at 250 and $610^{\circ} \mathrm{C}$, and, from analogy with other metals, aluminum evidently undergoes a transformation at these temperatures.

In 1907 Henning ${ }^{15}$ experimented with the same rod of aluminum used by Dittenberger, but obtained values which are somewhat higher than those given by the latter. The average coefficients of expansion, computed from Henning's data, are as follows:

TABLE 14.-Coefficients of Expansion of Aluminum (Henning)

\begin{tabular}{|c|c|c|c|}
\hline $\begin{array}{l}\text { Temperature interval in degrees } \\
\text { centigrade }\end{array}$ & $\begin{array}{l}\text { Average } \\
\text { coefficients }\end{array}$ & $\begin{array}{l}\text { Temperature interval in degrees } \\
\text { centigrade }\end{array}$ & $\begin{array}{l}\text { Average } \\
\text { coefficienta }\end{array}$ \\
\hline $\begin{array}{l}+16 \text { to }-191 . \ldots \ldots \\
+16 \text { to }+250 \ldots \ldots \ldots \ldots \\
+16 \text { to }+375 \ldots \ldots \ldots \ldots\end{array}$ & $\begin{array}{l}18.4 \times 10^{-6} \\
24.4 \\
26.3\end{array}$ & $\begin{array}{l}+16 \text { to }+500 \ldots \ldots \ldots \ldots \ldots \ldots \\
+16 \text { to }+610 \ldots \ldots \ldots \ldots \ldots \ldots\end{array}$ & $\begin{array}{l}27.2 \times 10^{-6}-6 \\
29.0\end{array}$ \\
\hline
\end{tabular}

In April, I919, Jaeger and Scheel ${ }^{16}$ reported data on the thermal expansion of two samples of aluminum containing, respectively, I.2 and 0.4 per cent of impurities, chiefly iron and silicon. The expansion is summed up by the approximate formula

$$
L_{t}=L_{0}\left[\mathrm{I}+\left(22.9 t+0.009 t^{2}\right) \mathrm{IO}^{-8}\right]
$$

between the limits -78 to $500^{\circ} \mathrm{C}$.

$14 \mathrm{Z}$. Ver. deutsch. Ing., 46, p. 1532; 1902.

15 Ann. d. Phys. (4), 22, p. $63 x ; 1907$.

16 Elekt. Zeits. 40, D. 150, Apr. 3, 1919. 
In the present investigation two samples were cut from a bar of aluminum of high purity, prepared by the Aluminum Company of America, New Kensington, $\mathrm{Pa}$.

The metal was melted in an Acheson graphite crucible at a temperature which at no time exceeded $135^{\circ} \mathrm{F}$ and was poured at $1300^{\circ} \mathrm{F}$ in a green sand mold. The bar was taken directly from the mold and received no further heat treatment before the thermal expansion tests. The analysis of samples taken from the ends of the bar after it was cast was as follows:

Silicon..............................................

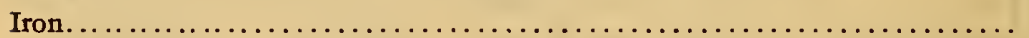

0. 12

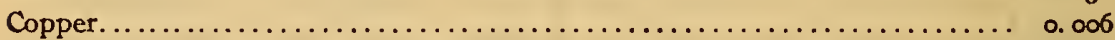

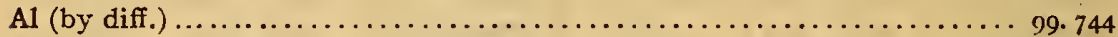

The following table gives the results obtained for the average coefficients of expansion for various temperature ranges:

TABLE 15.-Coefficients of Expansion of Aluminum

\begin{tabular}{|c|c|c|c|c|c|}
\hline \multirow{2}{*}{$\begin{array}{c}\text { Temperature range in } \\
\text { degrees centigrade }\end{array}$} & \multicolumn{2}{|c|}{ Average coefficients } & \multirow{2}{*}{$\begin{array}{l}\text { Temperature range in } \\
\text { degrees centigrade }\end{array}$} & \multicolumn{2}{|c|}{ Average coefficienta } \\
\hline & $\underset{(\mathrm{S} 613)}{\text { Sample } 1}$ & $\underset{(\text { S615) }}{\text { Sample } 2}$ & & $\underset{(\mathrm{S} 613)}{\text { Sampie } 1}$ & $\begin{array}{c}\text { Sample } 2 \\
(\mathrm{~S} 615)\end{array}$ \\
\hline 20 to $100 \ldots$ & $23.7 \times 10^{-6}$ & $23.8 \times 10^{-6}$ & 500 to $600 \ldots$ & $35.9 \times 10^{-6}$ & $36.2 \times 10^{-0}$ \\
\hline 100 to $200 \ldots \ldots \ldots$ & 25.4 & 26.1 & 20 to $300 \ldots \ldots \ldots \ldots \ldots$ & 25.6 & 25.7 \\
\hline 200 to $300 \ldots \ldots . . . . . .$. & 27.3 & 27.0 & 300 to $600 \ldots \ldots$ & 32.7 & 33. 1 \\
\hline 300 to $400 \ldots$ & 29.8 & 30.2 & 20 to $600 \ldots \ldots \ldots \ldots$ & 29.3 & 29.5 \\
\hline 400 to $500 \ldots .$. & 32.3 & 32.9 & & & \\
\hline
\end{tabular}

The average equation

$$
L_{\mathrm{t}}=L_{\mathrm{o}}\left[\mathrm{I}+\left(2 \mathrm{I} .90 t+0.0 \mathrm{I} 20 t^{2}\right) \mathrm{IO}^{-8}\right]
$$

is given as the most probable second-degree equation for the expansion of this aluminum (99.74 per cent) from room temperature to $600^{\circ} \mathrm{C}$. The length at any temperature $t$ as determined from this equation is accurate to \pm 0.00004 per unit length.

Observations were taken on cooling on sample $\mathrm{I}\left(\mathrm{S}_{6} \mathrm{I}_{3}\right)$ and are plotted in Fig. Io. The cooling curve was found to be slightly above the heating curve, and at the end of the test the specimen was about o.o I per cent longer than before the test. The length of the other specimen was practically the same before and after the test. 
We have been unable to verify conclusively the irregularities ${ }^{17}$ which Dittenberger indicated at 250 and $610^{\circ} \mathrm{C}$. These were, perhaps, the result of impurities.

\section{SUMMARY}

This paper gives data on the thermal expansion of 29 samples of commercial nickel, monel metal, stellite, stainless steel, and aluminum, in addition to the results obtained by previous observers

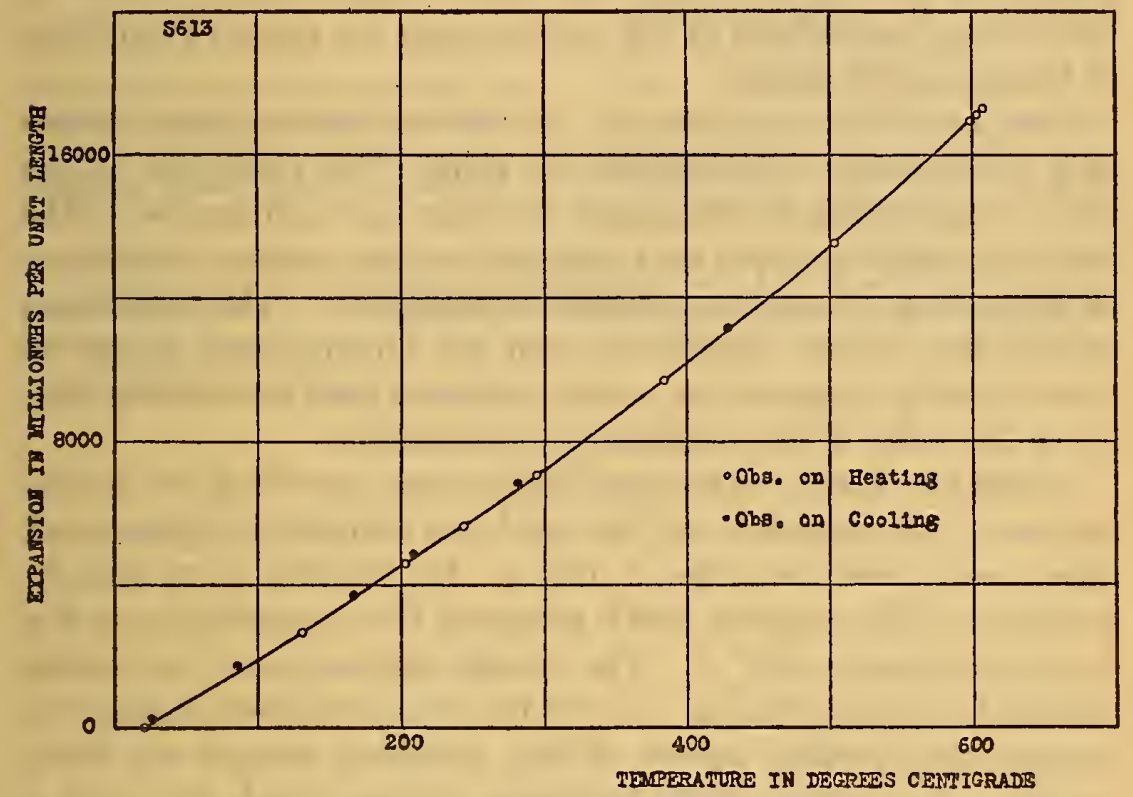

FIG. Io.-Thermal expansion of aluminum

on the expansion of nickel and aluminum. All of these materials except stainless steel were examined from toom temperature to about $600^{\circ} \mathrm{C}$. The samples of stainless steel were heated from room temperature to $900^{\circ} \mathrm{C}$. The apparatus used was essentially the same as that described in Scientific Papers of the Bureau of Standards, No. 352 .

NICKEL. - In most of the expansion curves of commercial nickel a slight irregularity was perceptible in the region near

\footnotetext{
${ }_{17} \mathrm{~J}$. D. Edwards, of the Aluminum Co. of America, suggests a number of possible explanations for the irregularities in the thermal expansion of aluminum at 250 and $610^{\circ} \mathrm{C}$. "It may be only a coincidence, but the temperature of recrystallization of aluminum is about $250^{\circ} \mathrm{C}$, and if these other investigators had been using cold-rolled specimens they might have noticed a break in the curve at that temperature. The specimens sent to the Bureau wcre cast, and of course no recrystallization would be expected in them. Furthermore, the solubility of certain elements, such as iron and silicon in aluminum, is very low, and the presence of those impurities changing from solid solution might produce an irregularity in the results.
} 
$350^{\circ} \mathrm{C}$, but there was no marked change or anomalous expansion such as was observed by previous investigators in the case of pure nickel. Annealing of the hot-rolled samples of nickel usually caused a slight increase in the values of the coefficients of expansion.

MONEL METAL. - The expansion curves of monel metal were found to be fairly regular. The average coefficients of expansion of the various samples for the range from 25 to $300^{\circ} \mathrm{C}$ are all practically equal. For the temperature range from 25 to $600^{\circ} \mathrm{C}$, the average coefficients of the cast samples are greater than those of the hot-rolled alloys.

STELLITE.-For the samples of stellite (except festel metal) only approximate compositions are given. The expansion curves show irregularities in the region between 300 and $500^{\circ} \mathrm{C}$. The stellite containing to per cent tungsten has the smallest coefficients of expansion of all the samples investigated. The hammered stellite has smaller coefficients than the unhammered sample of corresponding composition, which indicates that hammering may lower the value of the coefficients of expansion.

STAINLESS STEEL.-The expansion curves, including the critical regions of the annealed and the hardened sample of stainless steel, have been shown in Figs. 8 and 9. On heating, both samples indicated critical regions which extended from approximately 825 to approximately $855^{\circ} \mathrm{C}$. The transformation point on cooling occurred at about $800^{\circ} \mathrm{C}$. Up to the transformation regions the heating and cooling curves of the annealed sample are fairly reguiar. In the case of the hardened stainless steel, the curve is irregular between 200 and $400^{\circ} \mathrm{C}$ where the strains produced in hardening were released. Above $400^{\circ}$ this sample behaved like the annealed specimen. The coefficients of expansion of the hardened or annealed stainless steel are less than the coefficients of ordinary iron or steel, which is probably due to the large amount of chromium.

Aldminum.-The thermal expansion of the two samples of aluminum investigated between room temperature and $600^{\circ} \mathrm{C}$ may be represented by the following empirical equation:

$$
L_{\mathrm{t}}=L_{\mathrm{o}}\left[\mathrm{I}+\left(2 \mathrm{I} .90 t+0.0 \mathrm{I} 20 t^{2}\right) \mathrm{IO}^{-8}\right] .
$$

The thermal expansion of aluminum was found to be approximately twice as large as that of any of the other materials discussed in this paper. 
For comparison the average coefficients of expansion of the materials investigated for several temperature ranges are given in the following table:

TABLE 16.-Average Coefficients of Expansion of Nickel, Monel Metal, Stellite, Stainless Steel, and Aluminum

\begin{tabular}{|c|c|c|c|c|}
\hline \multirow[b]{2}{*}{ Materials } & \multicolumn{4}{|c|}{ Average coefficients of expansion $\times 10^{8}$} \\
\hline & $\begin{array}{l}\text { Room tem- } \\
\text { perature } \\
\text { to } 100^{\circ} \mathrm{C}\end{array}$ & $\begin{array}{c}\text { Room tem- } \\
\text { perature } \\
\text { to } 300^{\circ} \mathrm{C}\end{array}$ & $\begin{array}{l}300 \text { to } \\
600^{\circ} \mathrm{C}\end{array}$ & $\begin{array}{l}\text { Room tem- } \\
\text { perature } \\
\text { to } 600^{\circ} \mathrm{C}\end{array}$ \\
\hline 10 sampies of commercial nickel ( 94 to 99 per cent).. & 12.9 to 13.5 & 13.8 to 14.6 & 15. 3 to 17.0 & 14.9 to 15.7 \\
\hline 10 samples of monel metal ( 60 to 69 per cent $\mathrm{Ni}$ ).... & 13.7 to 14.5 & 14.9 to 15.2 & 16.6 to 18.4 & 15.9 to 16.7 \\
\hline 5 samples of stellite ( 22 to 80 per cent $\mathrm{Co}$ ).............. & 11. 0 to 15.6 & 12.41016 .7 & 14.7 to 18.0 & 13. 6 to 17.1 \\
\hline 2 samples of stainless steel $a\left(13\right.$ per cent $\left.C_{r}\right) \ldots \ldots \ldots$ & 9.6 to 10.3 & $\ldots \ldots \ldots . . . . .$. & $\ldots \ldots . . . . . . .$. & 11.2 to 12.1 \\
\hline 2 samples of aluminum...................... & 23. 7 to 23.8 & 25.6 to 25.7 & 32.7 to 33.1 & 29.3 to 29.5 \\
\hline
\end{tabular}

a The smaller values refer to a hardened sample and the larger values to an annealed sample of stainiess steel. For the range from 600 to $800^{\circ} \mathrm{C}$ the average coefficients of expansion were $13.4 \times 10^{-6}$ and $13.6 \times 10^{-6}$, respectively.

WASHINGTON, May 6, I921. 